\title{
BMJ Open Toxoplasma gondii infection in pregnant women: a cross-sectional study in Matehuala City, Mexico
}

\author{
Ada-Agustina Sandoval-Carrillo, ${ }^{1}$ Angel Antonio Vértiz-Hernández, ${ }^{2}$ \\ Jose-Manuel Salas-Pacheco, ${ }^{1}$ Olga Edith González-Lugo, ${ }^{2}$ \\ Elizabeth-Irasema Antuna-Salcido, ${ }^{1}$ Sergio Manuel Salas-Pacheco, ${ }^{1}$ \\ Luis Francisco Sánchez-Anguiano, ${ }^{1}$ Edna Madai Méndez-Hernández, ${ }^{3}$ \\ Jesús Hernández-Tinoco, ${ }^{1}$ Francisco Xavier Castellanos-Juárez, ${ }^{4}$ \\ Osmel La-Llave-León (1D , ${ }^{1}$ Cosme Alvarado-Esquivel (i) ${ }^{5}$
}

To cite: Sandoval-Carrillo AA, Vértiz-Hernández AA, Salas-Pacheco J-M, et al. Toxoplasma gondii infection in pregnant women: a crosssectional study in Matehuala City, Mexico. BMJ Open 2020;10:e033995. doi:10.1136/ bmjopen-2019-033995

- Prepublication history and additional material for this paper are available online. To view these files, please visit the journal online (http://dx.doi. org/10.1136/bmjopen-2019033995).

Received 02 September 2019 Revised 18 February 2020 Accepted 22 June 2020

Check for updates

(c) Author(s) (or their employer(s)) 2020. Re-use permitted under CC BY-NC. No commercial re-use. See rights and permissions. Published by BMJ.

For numbered affiliations see end of article.

Correspondence to

Dr Cosme Alvarado-Esquivel; alvaradocosme@yahoo.com

\section{ABSTRACT}

Objectives This study aimed to determine the seroprevalence of Toxoplasma gondii (T. gondii) infection in pregnant women in Matehuala City, Mexico; and the associated risk factors.

Design A cross-sectional study.

Setting Matehuala City, Mexico.

Participants 311 pregnant women.

Primary and secondary outcome measures Sera of women were analysed for anti-T. gondii lgG and IgM antibodies by commercially available immunoassays. Bivariate and multivariate analyses were used to assess the association between $T$. gondii seroprevalence and the characteristics of the pregnant women.

Results Thirteen (4.2\%) of the 311 pregnant women studied were positive for anti-T. gondii IgG antibodies. No anti- T. gondii IgM antibodies were found in antiT. gondii IgG seropositive women. No association between seropositivity and history of blood transfusion, transplantation, caesarean sections, deliveries, miscarriages or number of pregnancies was found. Logistic regression analysis of sociodemographic, behavioural and housing variables showed that availability of potable water at street represented a risk factor for T. gondii infection (age-adjusted OR=2.18; 95\% Cl: 1.05 to 4.53; $p=0.03$ ), whereas being born in Mexico was a protective factor for infection (age-adjusted $\mathrm{OR}=0.01$; $95 \% \mathrm{Cl}: 0.001$ to $0.35 ; \mathrm{p}=0.008$ ).

Conclusions In this first study on the seroepidemiology of $T$. gondii infection in pregnant women in Matehuala, we conclude that the seroprevalence of $T$. gondii infection is low and similar to those reported in pregnant women in other Mexican cities. However, the seroprevalence found is lower than those reported in pregnant women in other countries in the Americas and Europe. Two risk factors associated with $T$. gondii infection were identified. Results of the present study may help for the optimal planning of preventive measures against toxoplasmosis in pregnant women.

\section{INTRODUCTION}

Toxoplasmosis is a disease caused by the parasite Toxoplasma gondii (T. gondii). ${ }^{1}$ This

\section{Strengths and limitations of this study}

- This is the first study of Toxoplasma gondii (T. gondii) infection in pregnant women in the central Mexican city of Matehuala.

- This study provides information about the immunological status against $T$. gondii in pregnant women in a previously unexplored central Mexican city.

- A low seroprevalence of $T$. gondii infection in the studied pregnant women was found.

- The current work shows risk factors for $T$. gondii infection found in pregnant women that may help for the planning of measures against toxoplasmosis and its sequelae.

- The low rate of seropositivity to $T$. gondii did not allow the finding of further associations between the characteristics of pregnant women and $T$. gondii infection.

parasite is a coccidian of the phylum Apicomplexa $^{2}$ and causes infections worldwide. ${ }^{3}$ Transmission of $T$. gondii occurs mainly by ingestion of parasite oocysts shed by cats or by consumption of tissue cysts in meat from infected animals. ${ }^{4}$ The parasite may cross the placenta of an infected woman and may infect the fetus congenitally. ${ }^{5}$ Congenital infection with T. gondii may have severe consequences as miscarriage, fetal death and neurological, ocular and another organ damage in the fetus. ${ }^{6}$ If the infection occurs in an early phase of pregnancy the rate of transmission is low, but the severity is high if the fetus is infected; whereas if the infection occurs in a late phase of pregnancy the transmission rate is higher, and the severity would be low. ${ }^{5}$ On the other hand, infections with $T$. gondii that occur after birth are usually asymptomatic, but the parasite may induce severe disease in immunocompromised patients. ${ }^{7}$ Toxoplasmosis is 
Table 1 A summary of epidemiological data about Toxoplasma gondii (T. gondii) infection in studies in pregnant women in Mexico

\begin{tabular}{|c|c|c|c|c|c|c|c|}
\hline \multirow{2}{*}{$\begin{array}{l}\text { Study } \\
\text { population }\end{array}$} & \multirow{2}{*}{$\begin{array}{l}\text { Year of the } \\
\text { publication of the } \\
\text { study }\end{array}$} & \multirow{2}{*}{$\begin{array}{l}\text { Place of the } \\
\text { study }\end{array}$} & \multirow{2}{*}{$\begin{array}{l}\text { Women } \\
\text { tested No. }\end{array}$} & \multicolumn{2}{|c|}{$\begin{array}{l}\text { Prevalence of } T \text {. } \\
\text { gondii infection }\end{array}$} & \multirow[b]{2}{*}{ Risk factors } & \multirow[b]{2}{*}{ Reference } \\
\hline & & & & No. & $\%$ & & \\
\hline $\begin{array}{l}\text { Women in rural } \\
\text { area in northern } \\
\text { Mexico }\end{array}$ & 2009 & Durango State & 439 & 36 & 8.2 & $\begin{array}{l}\text { Low socioeconomic } \\
\text { conditions, soil floor at } \\
\text { home }\end{array}$ & 11 \\
\hline
\end{tabular}

a life-threatening disease for transplant recipients under immunosuppression. ${ }^{8}$

Very little is known about the seroepidemiology of $T$. gondii infection in pregnant women in Mexico. A 34.9\% seroprevalence of $T$. gondii infection was found in pregnant women with high risk pregnancies in the central Mexican city of Guadalajara. ${ }^{9}$ Whereas seroprevalences of $6.1 \%$ and $8.2 \%$ were found in pregnant women in the northern Mexican city of Durango, ${ }^{10}$ and rural Durango, ${ }^{11}$ respectively. Seroprevalences of $3.6 \%$ and $6.2 \%$ were found in women of reproductive age in the northwestern Mexican city of Hermosillo, ${ }^{12}$ and in pregnant women in the central Mexican city of Aguascalientes ${ }^{13}$ respectively. A summary of epidemiological data of previous studies of T. gondii infection in pregnant women in Mexico is shown in table 1 . The seroepidemiology of $T$. gondii infection in pregnant women in the central Mexican city of Matehuala is unknown. This study aimed to determine the seroprevalence of $T$. gondii infection and the factors associated with this infection in pregnant women in Matehuala. The original protocol for the study is shown in online supplementary file 1 .

\section{MATERIALS AND METHODS}

\section{Study design and pregnant women studied}

Through a cross-sectional study design, we studied 311 pregnant women in Matehuala City, Mexico. This city is located in the central Mexican state of San Luis Potosí (figure 1) [https://www.google.es/ maps/place/Matehualahttps://www. google.es/ maps/place/ Matehuala,+S .L.P./@23.6543156,$100.6464011,14 \mathrm{z} / \mathrm{data}=! 4 \mathrm{~m} 5 ! 3 \mathrm{~m} 4 ! 1 \mathrm{~s} 0 \times 867 \mathrm{e} 1 \mathrm{~d}-$ 86694082f9:0×4016978679cc460!8m2!3d23.644802 9 !4d-100.64279].

Inclusion criteria were: (1) pregnant women attended in the General Hospital of the Health Services in Matehuala City, Mexico; and (2) aged 18 years and older. This study was performed from January to April 2018. For calculation of the sample size we used a reference seroprevalence of $6.2 \%{ }^{13}$ as expected frequency of $T$. gondii seropositivity, 15000 as the population size, $3.0 \%$ of confidence limits and a confidence level of $97 \%$. The result of the calculation was 298 subjects.

\section{Sociodemographic, clinical, behavioural and housing data of} pregnant women

Sociodemographic, clinical, housing and behavioural characteristics of the pregnant women were obtained using a standardised questionnaire. Sociodemographic

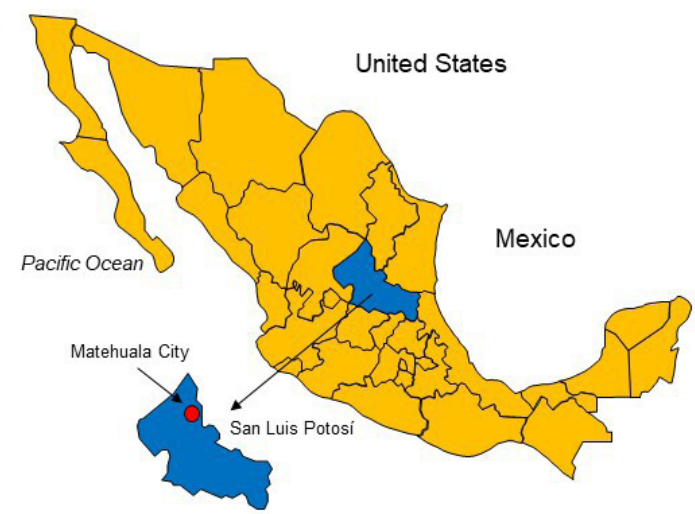

Figure 1 Geographical location of Matehuala City. This City is located at the North of San Luis Potosí state, Mexico. 
data included birthplace, residence, age, gender, socioeconomic status, education and occupation. Clinical data included history of transplant or blood transfusion, number of pregnancies, deliveries, caesarean sections and miscarriages. Behavioural data included consumption of untreated water or unpasteurised milk, unwashed raw vegetables or fruits, contact with animals, contact with cat faeces, type of meat consumed, degree of meat cooking, consumption of dried or cured meat, frequency of eating out of home, contact with soil and travelling. Housing data included type of flooring, water supply, form of elimination of excretes, crowding at home and education of the head of the family.

\section{Sample collection and processing}

Each pregnant woman provided a blood sample. After centrifugation of blood, sera were obtained and frozen at $-20^{\circ} \mathrm{C}$ until analysed.

\section{Detection of anti-T. gondii IgM and IgG antibodies}

Detection of anti-T. gondii $\operatorname{IgG}$ antibodies was performed using a commercially available enzyme immunoassay 'Toxoplasma gondii IgG' kit (Diagnostic Automation/ Cortez Diagnostics, Inc, Woodland Hills, California. USA). Samples positive for anti-T. gondii IgG were additionally analysed for anti- $T$. gondii IgM antibodies by a commercially available enzyme immunoassay 'Toxoplasma gondii IgM' kit (Diagnostic Automation/Cortez Diagnostics, Inc). IgG and IgM tests were performed following the instructions of the manufacturer.

\section{Statistical analysis}

The statistical analysis was performed with the aid of the software Epi Info V.7, and SPSS V.20 (SPSS Inc, Chicago, Illinois, USA). We compared the frequencies of seropositivity among groups using the Fisher's exact test. Logistic regression analysis with the Enter method was used to determine the association between the characteristics of the pregnant women and the seropositivity to $T$. gondii. To avoid bias, clinical characteristics were analysed separately from other characteristics of pregnant women. Subjects with missing values were excluded. Variables with a $\mathrm{p}$ value $\leq 0.15$ obtained in the bivariate analysis were included in the regression analysis. We calculated the age-adjusted OR and $95 \%$ CI, and a $\mathrm{p}$ value $<0.05$ was considered as statistically significant.

Participation in the study was voluntary. Information about the objectives and procedures of the study was provided to participants, and a written informed consent was obtained from all of them.

\section{Patients and public involvement}

This research was done without patient involvement. Patients were not invited to comment on the study design and were not consulted to develop patient-relevant outcomes or interpret the results. Patients were not invited to contribute to the writing or editing of this document for readability or accuracy.
Table 2 Sociodemographic characteristics of pregnant women and seroprevalence of Toxoplasma gondii (T. gondii) infection

\begin{tabular}{|c|c|c|c|c|}
\hline \multirow[b]{2}{*}{ Characteristic } & \multirow{2}{*}{$\begin{array}{l}\text { Subjects } \\
\text { tested No. }\end{array}$} & \multicolumn{2}{|c|}{$\begin{array}{l}\text { Prevalence of } T \text {. } \\
\text { gondii infection }\end{array}$} & \multirow[b]{2}{*}{$\mathrm{P}$ value } \\
\hline & & No. & $\%$ & \\
\hline \multicolumn{5}{|l|}{ Age groups (years) } \\
\hline $18-30$ & 231 & 8 & 3.9 & 0.74 \\
\hline $31-44$ & 80 & 4 & 5.0 & \\
\hline \multicolumn{5}{|l|}{ Birthplace } \\
\hline Mexico & 309 & 12 & 3.9 & 0.08 \\
\hline Abroad & 2 & 1 & 50.0 & \\
\hline \multicolumn{5}{|l|}{ Residence area } \\
\hline Urban & 227 & 9 & 4.0 & 0.38 \\
\hline Suburban & 23 & 0 & 0.0 & \\
\hline Rural & 61 & 4 & 6.6 & \\
\hline \multicolumn{5}{|l|}{ Educational level } \\
\hline No education & 8 & 1 & 12.5 & 0.28 \\
\hline 1 to 6 years & 253 & 12 & 4.7 & \\
\hline $7-12$ years & 49 & 0 & 0.0 & \\
\hline$>12$ years & 1 & 0 & 0.0 & \\
\hline \multicolumn{5}{|l|}{ Occupation } \\
\hline Housewife & 190 & 11 & 5.8 & 0.75 \\
\hline Business & 2 & 0 & 0.0 & \\
\hline Employee & 89 & 2 & 2.2 & \\
\hline Student & 15 & 0 & 0.0 & \\
\hline $\begin{array}{l}\text { Professional in } \\
\text { biomedical area }\end{array}$ & 4 & 0 & 0.0 & \\
\hline $\begin{array}{l}\text { Professional in } \\
\text { non-biomedical } \\
\text { area }\end{array}$ & 5 & 0 & 0.0 & \\
\hline None & 6 & 0 & 0.0 & \\
\hline \multicolumn{5}{|c|}{ Socioeconomic level } \\
\hline Low & 181 & 9 & 5.0 & 0.41 \\
\hline Medium & 130 & 4 & 3.1 & \\
\hline
\end{tabular}

\section{RESULTS}

Pregnant women were 18 to 44 (mean: $26.14 \pm 5.97)$ years old and were studied during their 1 to 9 (median: 7) month of pregnancy. Thirteen (4.2\%) of the 311 pregnant women studied were positive for anti-T. gondii IgG antibodies. None of these anti- $T$. gondii seropositive women were positive for anti-T. gondii $\operatorname{IgM}$ antibodies. Table 2 shows the association between the sociodemographic characteristics of the pregnant women and the seroprevalence of $T$. gondii infection.

As to clinical characteristics, no association ( $p>0.05)$ between seropositivity to T. gondii and history of blood transfusion, transplantation, caesarean sections, deliveries, miscarriages or number of pregnancies was found. 
With respect to behavioural and housing characteristics, only the variables availability of potable water and education of the head of the family showed $p$ values lower than 0.15 by bivariate analysis. Table 3 shows results of the bivariate analysis of a selection of behavioural and housing characteristics and seroreactivity to $T$. gondii. Logistic regression analysis of sociodemographic, behavioural and housing characteristics with $\mathrm{p}<0.15$ obtained by bivariate analysis showed that $T$. gondii infection was positively associated with availability of potable water at street (age-adjusted $\mathrm{OR}=2.18 ; 95 \% \mathrm{CI}: 1.05$ to 4.53; $\mathrm{p}=0.03$ ), and negatively associated with being born in Mexico (age-adjusted OR=0.01; 95\% CI: 0.001 to 0.35; $\mathrm{p}=0.008$ ). Results of the regression analysis are shown in table 4 .

\section{DISCUSSION}

Very little is known about the seroepidemiology of $T$. gondii infection in pregnant women in Mexico. This study aimed to determine the magnitude of the infection with T. gondii in a sample of pregnant women in the northern Mexican city of Matehuala. The seroprevalence found in the present study is similar to T. gondii seroprevalences reported in pregnant women in other northern Mexican cities including Durango (6.1\%), ${ }^{10}$ and Aguascalientes $(6.2 \%)^{13}$ and women at reproductive age in the northwestern Mexican city of Hermosillo, Sonora $(3.6 \%) .{ }^{12} \mathrm{On}$ the other hand, the seroprevalence of $T$. gondii infection found in the present study is lower than the $8.2 \%$ seroprevalence of this infection found in pregnant women in rural Durango State. ${ }^{11}$ These studies used the same immunoassay to detect anti- $T$. gondii IgG antibodies. In the Americas context, the seroprevalence found in this study is lower than the $39.8 \%$ to $51 \%$ seroprevalence of $T$. gondii infection reported in pregnant women in Cali City, Colombia; ${ }^{14}$ Bahia State, Brazil $;{ }^{15}$ and 10 English-speaking Caribbean countries. ${ }^{16}$ In addition, the seroprevalence found in pregnant women in Matehuala City is lower than the $11.1 \%$ to $21.9 \%$ seroprevalences of $T$. gondii infection reported in European countries including Spain, ${ }^{17}$ Portugal, ${ }^{18}$ Turkey ${ }^{19}$ and Sweden. ${ }^{20}$ It is not clear why the seroprevalence found in the current study is lower than those reported in pregnant women in other countries. Differences in the characteristics of the pregnant women and type of environment among the compared countries might explain the differences in the T. gondii seroprevalences. In general, it is likely that the parasite circulates in a low rate in Mexico. In fact, a study performed in the northern Mexican state of Durango showed a low rate of T. gondii infection in cats and other animals. ${ }^{21}$ However, there are specific population groups in Mexico with a high seroprevalence of $T$. gondii infection; for instance, miners in Durango State who had a seroprevalence of $60 \%{ }^{22}$ We looked for sociodemographic, behavioural and housing characteristics associated with $T$. gondii seropositivity. Logistic regression analysis showed that $T$. gondii infection was positively associated with availability
Table 3 Bivariate analysis of a selection of behavioural and housing characteristics and infection with Toxoplasma gondi (T. gondii) in pregnant women

\begin{tabular}{|c|c|c|c|c|}
\hline \multirow[b]{2}{*}{ Characteristic } & \multirow{2}{*}{$\begin{array}{l}\text { Subjects } \\
\text { tested No. }\end{array}$} & \multicolumn{2}{|c|}{$\begin{array}{l}\text { Prevalence of } T \text {. } \\
\text { gondii infection }\end{array}$} & \multirow[b]{2}{*}{ P value } \\
\hline & & No. & $\%$ & \\
\hline \multicolumn{5}{|l|}{ Cats at home } \\
\hline Yes & 100 & 2 & 2.0 & 0.23 \\
\hline No & 211 & 11 & 5.2 & \\
\hline \multicolumn{5}{|c|}{ Raising farm animals } \\
\hline Yes & 184 & 7 & 3.8 & 0.77 \\
\hline No & 127 & 6 & 4.7 & \\
\hline \multicolumn{5}{|l|}{ National trips } \\
\hline Yes & 231 & 11 & 4.8 & 0.52 \\
\hline No & 80 & 2 & 2.5 & \\
\hline \multicolumn{5}{|c|}{ Beef consumption } \\
\hline Yes & 291 & 12 & 4.1 & 0.58 \\
\hline No & 20 & 1 & 5.0 & \\
\hline \multicolumn{5}{|l|}{$\begin{array}{l}\text { Sheep meat } \\
\text { consumption }\end{array}$} \\
\hline Yes & 78 & 2 & 2.6 & 0.52 \\
\hline No & 233 & 11 & 4.7 & \\
\hline
\end{tabular}

Venison consumption

$\begin{array}{ccccc}\text { Yes } & 20 & 1 & 5.0 & 0.58 \\ \text { No } & 291 & 12 & 4.1 & \\ \text { Horse meat consumption } & & & \\ \text { Yes } & 5 & 1 & 20.0 & 0.19 \\ \text { No } & 306 & 12 & 3.9 & \end{array}$

Snake meat consumption

\begin{tabular}{ccccc} 
Yes & 14 & 1 & 7.1 & 0.45 \\
No & 297 & 12 & 4.0 & \\
\multicolumn{2}{r}{ Rat meat consumption } & & & \\
Yes & 30 & 2 & 6.7 & 0.36 \\
No & 281 & 11 & 3.9 &
\end{tabular}

Sausages consumption

$\begin{array}{ccccc}\text { Yes } & 275 & 13 & 4.7 & 0.37 \\ \text { No } & 36 & 0 & 0.0 & \\ \text { Soil contact } & & & & \\ \text { Yes } & 150 & 7 & 4.7 & 0.78 \\ \text { No } & 161 & 6 & 3.7 & \end{array}$

Floor at home

$\begin{array}{lllll}\begin{array}{l}\text { Ceramic or } \\ \text { wood }\end{array} & 150 & 4 & 2.7 & 0.37 \\ \text { Concrete } & 157 & 9 & 5.7 & \\ \text { Soil } & 4 & 0 & 0.0 & \end{array}$

Availability of potable water

\begin{tabular}{lllll} 
In the home & 271 & 9 & 3.3 & 0.06 \\
In the land & 18 & 1 & 5.6 & \\
\hline
\end{tabular}

Continued 
Table 3 Continued

\begin{tabular}{|c|c|c|c|c|}
\hline \multirow[b]{2}{*}{ Characteristic } & \multirow{2}{*}{$\begin{array}{l}\text { Subjects } \\
\text { tested No. }\end{array}$} & \multicolumn{2}{|c|}{$\begin{array}{l}\text { Prevalence of } T \text {. } \\
\text { gondii infection }\end{array}$} & \multirow[b]{2}{*}{ P value } \\
\hline & & No. & $\%$ & \\
\hline In the street & 22 & 3 & 13.6 & \\
\hline \multicolumn{5}{|l|}{ Crowding at home } \\
\hline No & 160 & 10 & 6.2 & 0.16 \\
\hline Semi-crowded & 118 & 2 & 1.7 & \\
\hline Overcrowded & 33 & 1 & 3.0 & \\
\hline \multicolumn{5}{|c|}{ Education of the head of family } \\
\hline 7 years or more & 189 & 7 & 3.7 & 0.11 \\
\hline 4 to 6 years & 109 & 4 & 3.7 & \\
\hline Up to 3 years & 13 & 2 & 15.4 & \\
\hline
\end{tabular}

of potable water at street, and negatively associated with being born in Mexico. The association of T. gondii exposure and availability of potable water at the street suggests poor sanitary environment and socioeconomic status. It is possible that water can be contaminated with $T$. gondii when transported from the street sources to the houses. The use of unclean containers or contamination of water with soil during transport might contribute for $T$. gondii infection. There is poor knowledge about toxoplasmosis in Mexico. A recent study in housewives showed that this population group had a low knowledge about preventive measures against $T$. gondii infection. ${ }^{23}$ For its part, the negative association between $T$. gondii seropositivity and being born in Mexico suggests that $T$. gondii infection might have been acquired abroad.

The present study has some limitations, pregnant women were from a low or medium socioeconomic status, and participants were obtained from only one hospital. Therefore, further studies including also pregnant women of high socioeconomic status and obtained in several hospitals for a better understanding of the epidemiology of $T$. gondii infection should be conducted. Results of this study cannot be generalised to other pregnant women in Mexico. Anti-T. gondii IgM antibodies were determined only in sera of women with anti-T. gondii IgG antibodies. Anti-T. gondii IgM appears early during primary infection; however, detection of this marker alone without anti- $T$.

Table 4 Multivariate analysis of selected characteristics of pregnant women and their association with Toxoplasma gondii infection

\begin{tabular}{llll}
\hline Characteristic & $\begin{array}{l}\text { Age-adjusted } \\
\text { OR }\end{array}$ & $\mathbf{9 5 \%} \mathbf{C l}$ & P value \\
\hline $\begin{array}{l}\text { Birthplace } \\
\text { (Mexico) }\end{array}$ & 0.01 & 0.001 to 0.35 & 0.008 \\
$\begin{array}{l}\text { Availability of } \\
\text { potable water }\end{array}$ & 2.18 & 1.05 to 4.53 & 0.03 \\
$\begin{array}{l}\text { Education of the } \\
\text { head of family }\end{array}$ & 1.67 & 0.65 to 4.33 & 0.28 \\
\hline
\end{tabular}

gondii IgG cannot provide a reliable diagnosis of infection since a considerable number of false-positive results has been reported in anti- $T$. gondii IgM immunoassays. ${ }^{24}$

\section{CONCLUSIONS}

In this first study on the seroepidemiology of T. gondii infection in pregnant women in the northern Mexican city of Matehuala, we conclude that the seroprevalence of $T$. gondii infection is low and similar to those reported in pregnant women in other Mexican cities. However, the seroprevalence found is lower than those reported in pregnant women in other countries in the Americas and Europe. Risk factors associated with $T$. gondii infection identified in the present study should be considered for the optimal planning of measures to avoid T. gondii infection during pregnancy.

\section{Author affiliations}

${ }^{1}$ Instituto de Investigación Científica, Universidad Juárez del Estado de Durango, Durango, Mexico

${ }^{2}$ Coordinación Académica Regional Altiplano, Universidad Autónoma de San Luis Potosí, San Luis Potosí, Mexico

${ }^{3}$ Subdirección de Auxiliares de Diagnóstico y Tratamiento, Hospital Regional de Alta Especialidad de Ixtapaluca, Ixtapaluca, Mexico

${ }^{4}$ IIC, Universidad Juarez del Estado de Durango, Durango, Mexico

${ }^{5}$ Laboratorio de Investigación Biomédica, Juarez University of Durango State Faculty of Medicine and Nutrition, Durango, Mexico

Contributors CA-E, AAV-H, JH-T and J-MS-P designed the study protocol, performed the data analysis. CA-E wrote the manuscript. AAV-H, OLLL, LFSA and OEG-L obtained blood samples, submitted the questionnaires and performed the data analysis. A-AS-C, SMS-P, FXC-J, EMM-H and E-IA-S performed the laboratory tests. All authors read and approved the final version of the manuscript.

Funding This work was supported by Juarez University of Durango State, Mexico.

Map disclaimer The depiction of boundaries on this map does not imply the expression of any opinion whatsoever on the part of BMJ (or any member of its group) concerning the legal status of any country, territory, jurisdiction or area or of its authorities. This map is provided without any warranty of any kind, either express or implied.

Competing interests None declared.

Patient consent for publication Not required.

Ethics approval The Institutional Ethical Committee of the General Hospital of the Health Services in Matehuala City, Mexico, approved this study.

Provenance and peer review Not commissioned; externally peer reviewed.

Data availability statement Data are available upon reasonable request. All data relevant to the study are included in the article or uploaded as supplementary information. The data set analysed is available from the corresponding author on reasonable request.

Open access This is an open access article distributed in accordance with the Creative Commons Attribution Non Commercial (CC BY-NC 4.0) license, which permits others to distribute, remix, adapt, build upon this work non-commercially, and license their derivative works on different terms, provided the original work is properly cited, appropriate credit is given, any changes made indicated, and the use is non-commercial. See: http://creativecommons.org/licenses/by-nc/4.0/.

\section{ORCID iDs}

Osmel La-Llave-León http://orcid.org/0000-0003-2788-3344

Cosme Alvarado-Esquivel http://orcid.org/0000-0002-0367-6052 


\section{REFERENCES}

1 Rajapakse S, Weeratunga P, Rodrigo C, et al. Prophylaxis of human toxoplasmosis: a systematic review. Pathog Glob Health 2017;111:333-42.

2 Rahimi MT, Daryani A, Sarvi S, et al. Cats and Toxoplasma gondii: a systematic review and meta-analysis in Iran. Onderstepoort $J$ Vet Res 2015;82:e1-10.

3 Alavi SM, Alavi L. Toxoplasmosis in Iran: a guide for general physicians working in the Iranian health network setting: a systematic review. Caspian J Intern Med 2016;7:233-41.

4 Montoya JG, Liesenfeld O. Toxoplasmosis. Lancet 2004;363:1965-76.

5 Khan K, Khan W. Congenital toxoplasmosis: an overview of the neurological and ocular manifestations. Parasitol Int 2018;67:715-21.

6 Piao LX, Cheng JH, Aosai F, et al. Cellular immunopathogenesis in primary Toxoplasma gondii infection during pregnancy. Parasite Immunol 2018;40:e12570.

7 Schlüter D, Däubener W, Schares G, et al. Animals are key to human toxoplasmosis. Int J Med Microbiol 2014;304:917-29.

8 Dard C, Marty P, Brenier-Pinchart M-P, et al. Management of toxoplasmosis in transplant recipients: an update. Expert Rev Anti Infect Ther 2018;16:447-60.

9 Galván Ramírez ML, Soto Mancilla JL, Velasco Castrejón O, et al. Incidence of anti-Toxoplasma antibodies in women with highrisk pregnancy and habitual abortions. Rev Soc Bras Med Trop 1995;28:333-7

10 Alvarado-Esquivel C, Sifuentes-Alvarez A, Narro-Duarte SG, et al. Seroepidemiology of Toxoplasma gondii infection in pregnant women in a public hospital in northern Mexico. BMC Infect Dis 2006;6:113.

11 Alvarado-Esquivel C, Torres-Castorena A, Liesenfeld O, et al. Seroepidemiology of Toxoplasma gondii infection in pregnant women in rural Durango, Mexico. J Parasitol 2009;95:271-4.

12 Alvarado-Esquivel C, Corella-Madueno MAG, Hernandez-Tinoco J, et al. Seroepidemiology of Toxoplasma gondii Infection in Women of Reproductive Age: A Cross-Sectional Study in a Northwestern Mexican City. J Clin Med Res 2018;10:210-6.

13 Alvarado-Esquivel C, Terrones-Saldívar MDC, Hernández-Tinoco J, et al. Seroepidemiology of Toxoplasma gondii in pregnant women in Aguascalientes City, Mexico: a cross-sectional study. BMJ Open 2016;6:e012409.
14 Rosso F, Les JT, Agudelo A, et al. Prevalence of infection with Toxoplasma gondii among pregnant women in Cali, Colombia, South America. Am J Trop Med Hyg 2008;78:504-8.

15 Avelar MV, Martinez VO, Moura DLde, et al. Association between seroprevalence of IgG anti-Toxoplasma gondii and risk factors for infection among pregnant women in Climério de Oliveira Maternity, Salvador, Bahia, Brazil. Rev Inst Med Trop Sao Paulo 2017;59:e90.

16 Dubey JP, Verma SK, Villena I, et al. Toxoplasmosis in the Caribbean islands: literature review, seroprevalence in pregnant women in ten countries, isolation of viable Toxoplasma gondii from dogs from St. Kitts, West Indies with report of new T. gondii genetic types. Parasitol Res 2016;115:1627-34.

17 Ramos JM, Milla A, Rodríguez JC, et al. Seroprevalence of Toxoplasma gondii infection among immigrant and native pregnant women in Eastern Spain. Parasitol Res 2011;109:1447-52.

18 Lobo ML, Patrocinio G, Sevivas T, et al. Portugal and Angola: similarities and differences in Toxoplasma gondii seroprevalence and risk factors in pregnant women. Epidemiol Infect 2017;145:30-40.

19 Çınar Tanrıverdi E, Göktuğ Kadıoğlu B, Alay H, et al. Retrospective Evaluation of Anti-Toxoplasma gondii antibody among first trimester pregnant women admitted to Nenehatun maternity hospital between 2013-2017 in Erzurum. Turkiye Parazitol Derg 2018;42:101-5.

20 Petersson K, Stray-Pedersen B, Malm G, et al. Seroprevalence of Toxoplasma gondii among pregnant women in Sweden. Acta Obstet Gynecol Scand 2000;79:824-9.

21 Dubey JP, Velmurugan GV, Alvarado-Esquivel C, et al. Isolation of Toxoplasma gondii from animals in Durango, Mexico. J Parasitol 2009;95:319-22

22 Alvarado-Esquivel C, Pacheco-Vega SJ, Hernandez-Tinoco J, et al. High Prevalence of Toxoplasma gondii Infection in Miners: A Case-Control Study in Rural Durango, Mexico. J Clin Med Res 2016;8:870-7.

23 Velázquez-Hernández N, Avilés Ávila AY, Rivas-González MA, et al. Knowledge and practices regarding toxoplasmosis in housewives: a cross sectional study in a northern Mexican City. PLoS One 2019;14:e0222094.

24 Liesenfeld O, Press C, Montoya JG, et al. False-Positive results in immunoglobulin M (IgM) Toxoplasma antibody tests and importance of confirmatory testing: the Platelia Toxo IgM test. J Clin Microbiol 1997;35:174-8. 